\title{
SUBSCRIPTIONS FOR UNIVERSITIES AND OTHER INSTITUTIONS
}

One of the aims of the Ecclesiastical Law Society is to further education in Ecclesiastical Law, especially through the publication of the Journal. The Society of public Teachers of Law, which represents teachers of law in Universities and other institutions of higher education, publishes a list of "Minimum Holdings" with recommended Journals which ought to be available in reputable Law libraries. The Ecclesiastical Law Journal is included in the "Statement of Minimum Holdings for Law Libraries in England and Wales (revised 1993)" which was published in the SPTL Journal, [1993] Legal Studies 332.

The Ecclesiastical Law Journal is asterisked in Legal Studies as a publication suitable for specialist collections. "It is desirable that every university law library should seek to develop special strength in one or more areas ... Every law library should have at least some of the asterisked material, while a library claiming some strength in particular fields should seek to build on and beyond them". or are donated issues;

At present the following institutions in the UK subscribe to the Journal

Theological colleges: Trinity College, Bristol; St. Michael's College, Cardiff; Chichester Theological College; St. John's College Durham; The College of the Resurrection, Mirfield; St. Stephen's House, Oxford

University libraries: The Taylor law Library, University of Aberdeen; the Wills Memorial Library, University of Bristol; Exeter University Library; the Brotherton Library, University of Leeds; the Robinson Library, University of Newcastle Upon Tyne; Sussex University Library

Other academic institutions and special libraries: Lambeth Palace Library; the Library of Lincoln's Inn; The Middle Temple Library; The Borthwick Institute, York.

A notice for members who might like to donate subscriptions to institutions of which they are members is enclosed with this issue of the Journal.

J.D.C.H. 